\title{
Costs and Benefits of Green Roof Types for Cities and Building Owners
}

\author{
Sita H. van der Meulen \\ Faculty of Technology, Innovation \& Society, The Hague University of Applied Science, \\ Johanna Westerdijkplein 75, 2521 EN, The Hague, The Netherlands \\ e-mail: s.h.vandermeulen@hhs.nl
}

Cite as: van der Meulen, S. H., Costs and Benefits of Green Roof Types for Cities and Building Owners, J. sustain. dev. energy water environ. syst., 7(1), pp 57-71, 2019, DOI: https://doi.org/10.13044/j.sdewes.d6.0225

\begin{abstract}
Increasing urbanization and the effects of climate change will bring new challenges for cities, such as energy saving and supply of renewable energy, preventing urban heat islands and water retention to deal with more frequent downpours. A major urban surface, the surface of roofs, is nowadays hardly exploited and could be used to make cities more 'future proof' or resilient. Many Dutch municipalities have become aware that the use of green roofs as opposed to bituminous roofs positively contributes to these challenges and are stimulating building-owners to retrofit their building with green roofs. This study aims at comparing costs and benefits of roof types, focused on green roofs (intensive and extensive) both on building- and city scale. Core question is the balance between costs and benefits for both scales, given varying local conditions. Which policy measures might be needed in the future in order to apply green roofs strategically in regard to local demands? To answer this question the balance of costs and benefits of green roofs is divided into a public and an individual part. Both balances use a strengths, weaknesses, opportunities and threats framework to determine the chance of success for the application of green roofs, considering that the balance for green roofs on an individual scale influences the balance on a public scale. The outcome of this combined analyses in the conclusion verifies that a non-committal policy for green roofs is not an effective way to prepare the city sufficiently for future climate changes.
\end{abstract}

\section{KEYWORDS}

Green roofs, Green roof policy, Urban heat island, Climate change, Retrofitting rooftops, Heat stress, Water storage.

\section{INTRODUCTION}

Many municipalities have become aware of their vulnerability towards future climate challenges. Due to climate change rain showers will be heavier and occur more frequently, but also the phenomena 'Urban Heat Island' can become a future challenge [1]. To prevent these climate changes becoming serious hazards Carbon dioxide $\left(\mathrm{CO}_{2}\right)$ emissions must be reduced, and climate mitigations and adaptation measures must be implemented in urban planning $[1,2]$.

Too much hard surfaces or impermeable soil results in an enormous amount of rainwater in sewage systems after heavy showers [3] and also contributes to heat stress. At the same time, 21-25\% [4] of hardened and unused urban area can be found on 
rooftops. A way to improve the environmental quality in densely built city centres for both storm water and heat challenges could be covering or retrofitting flat roofs with green roofs.

Most studies about green roofs describe and investigate their technical or social benefits. There are studies about green roof policies [5-7] and the way green roofs can be used in urban planning $[1,8,9]$, but studies about the performance of green roofs in practice is lacking according to literature $[5,7,10]$ and weaknesses of green roofs can be hardly found [11].

For this paper the literature review regarding technical benefits can be divided into overall benefits studied for The Netherlands [12-14] and overall benefits worldwide [10] with even a literature overview [15] or supplementing trends and future developments [16]. More specific, literature is found about its water related benefits [3, 17-19], heat related benefits [20-24], energy related benefits [25], the influence on air- and water quality [26], and life cycle costs [4] of green roofs.

The goal of this paper is to analyse, why and how green roofs can be used and stimulated most effectively in order to prevent climate effects and achieve $\mathrm{CO}_{2}$ reductions in future city developments.

What is the impact of green roofs to a resilient city, and can costs be assigned according to the beneficiaries? To answer this question a recognition is necessary of the fact that the urban environment and building rooftops do not have the same owner. Hence, the division of costs and benefits is not self-evident if a municipality is stimulating rooftop owners. Could this mean that the success of installing green roofs for public benefit is depending on its chance of success for its private space? And if so, which factors determine success or failure the most?

An important note about this can be made that though green roofs are theoretically the perfect solution as a measure for urban climate change effects and a lot of Dutch cities started with green roof policies, these policies don't seem to work out as predicted. Rotterdam for instance replaced its focus for policy from green roofs in 2008 [27] to multifunctional roofs.

\section{METHODS}

In this paper, SWOT analysis made by Brudermann and Sangkakool [11] for green roofs in general which is shown in Table 1, is divided into two different spatial scales, one SWOT analysis for the private space (building scale, Table 2) and one for the public space (urban scale, Table 3). In this way all costs (internal weaknesses and external threats) and benefits (internal strengths and external opportunities) for green roofs are divided between those two scales and their owners. Literature research is used to find additional factors for a specific scale.

Table 1. SWOT analysis for green roofs in European cities with temperate climates of Bruderman and Sangkakool

\begin{tabular}{|c|c|c|}
\hline & Positive & Negative \\
\hline \multirow[b]{2}{*}{ Internal } & Strengths & Weaknesses \\
\hline & $\begin{array}{l}\text { Ability to reduce flood risks } \\
\text { Energy savings } \\
\text { Environmental benefits } \\
\text { Life quality and aesthetics } \\
\end{array}$ & $\begin{array}{c}\text { Installation and maintenance costs } \\
\text { Structural and static challenges } \\
\text { Possible damage }\end{array}$ \\
\hline \multirow[b]{2}{*}{ External } & Opportunities & Threats \\
\hline & $\begin{array}{c}\text { Climate change } \\
\text { Green roof policies } \\
\text { Public acceptance and awareness }\end{array}$ & $\begin{array}{l}\text { Legal and political constraints } \\
\text { Lack of knowledge } \\
\text { Scepticism of potential adopters }\end{array}$ \\
\hline
\end{tabular}


A SWOT framework organizes decision factors and shows internal and external relations. Results for costs and benefits through literature research can be divided and listed more easily, and it also frames the comparison. By using a SWOT framework mutually, most important relations and influences can be determined. In this way, the focus remains on the mechanism of the balance of both scales at an overall level. Among the interesting outcomes of using this method is that some external factors for one scale can be seen as internal factors for the other scale.

For both private and urban spatial scales strengths, weaknesses, opportunities and threats are defined. A comparison for each scale between strengths and weaknesses on the one hand and opportunities and threats on the other hand will be the foundation to discover if strengths and opportunities can be utilised to overcome weaknesses and counter threats [28]. In the conclusion, by combining both SWOT analysis, most important challenges of the implementation of green roofs can be determined in order to improve policy and future research.

\section{DEFINITIONS AND BOUNDARIES}

'Green roofs' is a general name for a lot of different green roof types. In this paper all plant-covered roofs with a growing medium are called 'green roofs'. Green roofs often have more than one function, they can be water-retaining, cooling, insulating, used as additional living-space or enlarge urban space and even provide urban agriculture or reduce $\mathrm{CO}_{2}$.

Green roofs can be roughly divided into intensive or extensive green roofs. The words intensive or extensive refer to the amount of maintenance needed and the thickness of the layer $[10,13]$. It is necessary to make this distinction because both types show a lot of differences regarding costs and benefits. A third category is mentioned in literatures: the semi-intensive roof, but as there are no specific results for this kind of roofs [13], this category will be ignored in this paper. Every green roof consists of four distinctive components, namely: vegetation layer (plants), soil or growing medium (substrate), drainage material and a filter layer. Overall health of the vegetation which is used plays a crucial role in a successful performance of green roofs [10].

Extensive green roofs are most widely used [10] and can almost be regarded as building material or roof finishing, the total package structure is at most $15 \mathrm{~cm}$ high, requires no maintenance or irrigation and hardly any constructive or building adjustments. The choice for vegetation is restricted due to the minimalistic construction and maintenance conditions, plants must be able to survive without regular irrigation and its roots must be short and soft. Sedum-species are commonly used as they only need $7 \mathrm{~cm}$ of substrate [10]. An extensive roof is in most situations not accessible.

Intensive green roofs on the other hand, with a package more than $20 \mathrm{~cm}$ and a wide range of vegetation options such as grass, bushes or even trees, require a lot of maintenance (fertilising, weeding and watering) but can function as roof gardens, parks or urban agriculture. In most situations buildings must be constructively adapted or designed to carry the extra weight [10]. An intensive roof must be easy accessible.

Efficiency and benefits of green roofs strongly depend on climate conditions, which influences plant growth. For this paper we focus on the Dutch climate, a maritime climate with mild temperatures during wintertime, frequent showers during the year and some hot, but quite mild summer days. This climate is in general quite similar to the climate of Denmark, France and Germany. An important note is that literature and studies about green roofs are made in countries with comparable climate [10], but for studies related to heat, which are mainly Mediterranean-based. Not very remarkable, as Germany is regarded as the front-runner on implementing green roofs in urban environment [10]. A study of the performance of a green roof depends on various parameters. Therefore 
only a general overview of the most influential parameters about costs and benefits will be given in this paper.

\section{GREEN ROOFS FOR THE PROPERTY OWNER}

For the property owner, short term return of investment and direct benefits are much more relevant than for municipality. Table 2 provides an overview of the most important factors for strengths, weaknesses, opportunities and threats related to the property owner, which are described in this chapter.

Table 2. SWOT analysis for green roofs on the private scale (property owner)

\begin{tabular}{|c|c|c|}
\hline & Positive & Negative \\
\hline & $\underline{\text { Strengths }}$ & Weaknesses \\
\hline Internal & $\begin{array}{l}\text { Energy savings } \\
\text { Life quality and aesthetics } \\
\text { Roof protection }\end{array}$ & $\begin{array}{c}\text { Installation and maintenance costs } \\
\text { Structural and static challenges } \\
\text { Possible damage } \\
\text { Visibility }\end{array}$ \\
\hline & Opportunities & Threats \\
\hline External & $\begin{array}{l}\text { Green roof policies } \\
\text { Higher asset value }\end{array}$ & $\begin{array}{c}\text { Legal and political constraints } \\
\text { Lack of knowledge } \\
\text { Alternatives }\end{array}$ \\
\hline
\end{tabular}

\section{Strengths}

According to Dakdokters Amsterdam (personal communication, February 13, 2017) the leading motive of the owner for the choice for a green roof is the additional use of the roof as outer (garden) space. This means that life quality and aesthetics is the most crucial factor to be considered for the property owner and even more important, an intensive accessible roof is preferred above an extensive roof.

Life quality and aesthetics. For extensive green roofs, which are not easily accessible, the most obvious aesthetic motive is a green view. For firms, green roofs integrated in architecture add to a green identity which could be indirectly contributing to their revenue if an environmental friendly appearance is needed [13]. An important spatial condition is that the green roof must be visible from an indoor viewpoint or street level.

Furthermore, indoor comfort improving benefits can be recognised, the effect of acoustic reduction for ambient or traffic noise for example. Green roofs can in general reduce reverberation by approximately $3 \mathrm{~dB}$. For the inner space they increase soundproofing quality by approximately $5-8 \mathrm{~dB}$, depending on the saturation of the substrate, but only for sound frequencies between 250 and $1,250 \mathrm{~Hz}$ [3].

A psychological benefit is the feeling to be autonomously and positively contributing to the improvement of urban environment [13]. Additional strengths can also be found in the improvement of social cohesion in neighbourhoods or even education. A nice illustration of this can be found in Rotterdam, the Schieblock, where on top of an old office building a roof-garden has been made. This roof-garden, maintained by local residents, provides vegetables for its restaurant and education for schoolchildren.

Protection of the roof. Life extension of bituminous roof covering is often said to be an important benefit for owners. Longevity of a roof doubles by the protection of a green layer due to limiting the thermal stress to which it is subjected. Bituminous covering can last 30 instead of 15-20 years. The lifespan of green extensive roofs is in general 30-50 years [3]. If an extensive green roof is properly constructed, a minimum of maintenance is needed [14]. 
Energy savings. Benefits of green roofs regarding energy savings can be addressed to property owners as savings on costs by improved insulation (for incoming and outgoing heat).

Insulation efficiency for reducing incoming heat is determined by the evaporation of the green roof, increment of shading and albedo [3]. High solar reflectance or albedo and high Thermal Emittance (TE) are characteristics of cool roofs. A high albedo can prevent storage of heat in building materials with a low thermal emittance. In Mediterranean countries white mortars and plaster were used in most ancient massive buildings (low thermal emittance) to reflect as much sunlight as possible [22]. Studies show that roofs with dense vegetation act as a passive cooling system, the heat entering the building can go down by about $60 \%$ compared with a roof without vegetation, depending on three variables: leaf area index, height of the plants and thermal conductivity of the substrate [24]. Cooling of the inner climate of older buildings therefore can reduce costs if air-conditioning is needed [29]. If no air-conditioning is used, it can provide a more comfortable inner climate during hot summer days (with a difference of approximately 3-5 degrees).

Insulation of green roofs in cold periods depends on volumetric moisture content of the soil, solar radiation, ambient outside temperature and snow [25]. A constant Rc value can therefore not be given or calculated, but is changing depending on these fluctuating parameters. However, the better the insulation of the existing roof construction, the less a green roof will contribute [3]. As building regulations in the Netherlands now prescribe a Rc value of $6.0 \mathrm{~m}^{2} \mathrm{~K} / \mathrm{W}$ for roof constructions, an unknown addition of green roof insulation will not be very effective for new buildings.

Another indirect energy saving benefit is that solar panels can be successfully combined with extensive green roofs [13]. Green (moss) roofs have a cooling effect, which gives higher efficiency of solar panels (extra yields of $0.25-0.5 \%$ per ${ }^{\circ} \mathrm{C}$ above $25^{\circ} \mathrm{C}$ ambient temperature [13] during hot summer days. Air temperature of a gravel- or bituminous roof can run up to 50 or even $70{ }^{\circ} \mathrm{C}$ in summer, temperatures above green roofs remain in general $35^{\circ} \mathrm{C}$.

In fact, environmental and energy saving benefits can be regarded as life quality as well, as insulation, cooling, biodiversity and air-quality contribute to a higher indoor comfort for the building owner.

Environmental benefits and flood risk reduction. Can be interesting as far as it concerns savings on costs, such as less damage after heavy showers and protection of the roof, though these benefits are additional and almost never the main reason for the choice of a property owner for a green roof.

\section{Weaknesses}

All weaknesses of green roofs as mentioned by Sangkakool and Bruderman [11], such as structural and static challenges, higher implementation and maintenance costs and possible damage (leakage or structural damage), are serious risks for the property owner.

Higher implementation and maintenance costs. Not all rooftops can be retrofitted with green roofs. Flat roofs or roofs with slope less than 7 degrees with bituminous covering are the easiest and cheapest to adapt with green roofs. The bearing capacity of these roofs will in general only permit the use of extensive green roofs. Most roofs in the Netherlands are constructed to carry a load of $1 \mathrm{kN} / \mathrm{m}^{2}$ for snow, a saturated green moss roof of $7 \mathrm{~cm}$ is permissible without the requirement of reinforcement construction if it replaces gravel [3]. For intensive roofs the bearing capacity of the construction must be investigated thoroughly and if needed reinforced, which is much more expensive. Return 
of investment costs is uncertain or negative. Most benefits cannot be financially quantified, only energy savings (cooling, solar panel profits) and longevity of bituminous roof covering [13]. Regarding the latter it can be said that the initial costs for construction and maintenance of a green roof will be more than of a bituminous roof and life cycle analyses have to take into account the energy needed for maintenance [12]. Energy savings by adding a green roof are relevant if the original roof was badly insulated.

Visibility. An important spatial condition for its strengths regarding aesthetics and life quality is that the green roof must be visible from street level, which is also another weakness, if the roof is not visible for the property owner himself, the mere thought of applying a green roof will be absent. Next to this, not all roofs are flat, or otherwise suitable for applying green roofs.

Regarding the parameters (shading, leaf area, thickness of layer) that determine the performance of green roofs for other functions than aesthetics, an intensive roof would be the best choice for almost all aforementioned strengths. Unfortunately, retrofitting existing rooftops with intensive green roofs is hardly realistic, and not only beneficial strengths but also weaknesses, such as higher costs, structural and static challenges, are significantly higher for intensive roofs.

\section{Opportunities}

The most serious external opportunity for property owners is obtaining a higher market price of its asset by adding more functional square meters. However, no specific research and results are available yet [13]. As added functional square meters by green roofs cannot be obtained by extensive green roof types, property-owners need external incentives.

Green roof policy. One of the most used methods to achieve the public benefits of green roofs, is an arrangement to grant public subsidies [6] for construction of green roofs. For example, in The Netherlands a green roof policy fits in a strategy to increase the natural capital of the city (so called Delta Programme), in order to improve cities' liveability and make them future- or climate proof (www.rijksoverheid.nl). Subsidies are applied by more than seventeen Dutch municipalities (www.groendak.nl). Conditions for these subsidies are often a certain amount of rainwater retention (from $15 \mathrm{~L} / \mathrm{m}^{2}$ ), a minimal surface of green roof $\left(6 \mathrm{~m}^{2}\right.$ at least $)$, and an obligation for a careful design and construction.

Reduction on different kind of taxes or levies (for example sewage rights or storm water drainage) can be locally or nationally arranged. In The Netherlands, a method to meet costs is by green roofs being a part of a tax reduction for green investments [6]. Apart from this, green roofs can lead to extra credits in environmental assessment scores such as BREAAM or Leadership in Energy and Environmental Design* (LEED).

Adapted building license procedures for buildings with green roofs are another interesting measure. In some foreign cities (Washington D. C. and Chicago) procedures are faster for buildings with green roofs [6]. Sometimes municipality's special advisors help people to submit applications for green roofs on buildings, as a complicated procedure could scare them off.

Of course, benefits for builders as adapted building license procedures and obligatory standards only count for new building or renovations, and do not help owners who want to replace their existing roof covering by green roofs.

\footnotetext{
* The 'Environmental Assessment Method' BREAAM has been developed by the British organization Building Research Establishment (BRE) which operates in 15 different countries, LEED can be regarded as the American equivalent of BREAAM (source: https://www.breeam.nl)
} 
When we look at the green roof policy of Rotterdam, which started in 2008, its main goal is water retention and therefore to end up with $400.000 \mathrm{~m}^{2}$ of green roofs in Rotterdam. Nowadays, almost $235.000 \mathrm{~m}^{2}$ of green roofs are applied. The municipality of Rotterdam stimulates building owners with subsidies, reduction of levies, information days, actions and personal advice. All types of green roofs are allowed that use proper layers, have a surface of at least $10 \mathrm{~m}^{2}$, can store water of at least $15 \mathrm{~L} / \mathrm{m}^{2}$, have a decent design and are carefully constructed. They expect front runners will set an example for others (municipality of Rotterdam, personal communication, May 18, 2017) therefore subsidies are being reduced, $20 \mathrm{EUR} / \mathrm{m}^{2}$ in 2017-2018 and $15 \mathrm{EUR} / \mathrm{m}^{2}$ in 2019-2020. Subsidies are ending by the end of 2020 or when budgets have been depleted earlier (www.rotterdam.nl).

Most municipalities hope that by giving these grants frontrunners or inventive architects will set an example for others. To advertise green roofs, municipalities organize actions such as contests and information days and have helpdesks or special advisors for free [6]. From this point of view not only further research will be needed, but also practices on different levels, and enhanced partnerships between academics, politics, market and private stakeholders [16].

\section{Threats}

Not all buildings can be, or are allowed to be retrofitted with green roofs. Due to the load, intensive roofs are in most cases impossible to implement on existing roofs. But not only building physics but also legal and political constraints can negatively influence the choice of property owner for a green roof. However, most threats are also result of the fact that green roof technologies and their appliances are still at an early stage [11].

Alternatives. If there is no need to apply a green roof, why should the owner consider applying one in the first place? Considering this, the choice for a green roof is merely taken by those who already sympathize with green roofs, as for a serious solution for certain challenges (insulation, acoustics, aesthetics) there are other more well-known and cheaper alternatives available. Efficiency of solar panels or cooling can also be obtained by a white roof for example [12], and installing a green roof to improve roof insulation is not a very efficient method [16].

Lack of knowledge. For those property owners who are financially able to invest, communication plays a major role in the choice to change a roof into a green roof. Currently, the lack of information for most owners and a lot of uncertainties about the subsidy application, construction and costs or benefits of green roofs area an impediment. Next to roof owners, also insurance companies have to be informed very well about the risks. Most information and experience of using roof surface efficiently is about installing solar panels, which is suitable for almost every south-oriented roof and has direct return of investment for the property owner. To return to the socially successful practice of the roof garden at the Schieblock building, it is uncertain if such an enterprise is financially prosperous enough for investing.

\section{Comparison}

Comparing strengths with opportunities (S-O), a higher asset value without financial help is only realistic if the green roof can be used as an outdoor space. Extensive green roofs don't seem to add any financial value for the property owner unless in combination with solar panels or a badly insulated roof.

Comparing opportunities with weaknesses (W-O), which are mainly costs, building constraints and other uncertainties, the intrinsic motivation of the property owner shows its importance. Richer and more environmentally aware property owners could choose 
for green roofs, but there is almost no need to invest in a green roof for citizens who have less to spend.

The threat which concerns a lack of information and availability of cheaper alternatives strongly influences the weaknesses with regard to financial concerns and uncertainties (W-T) of property owners [11] if a green roof would be needed and even possible to construct at all.

The use of strengths of green roofs cannot be achieved very easily or obviously, so it is seriously limited by threats $(\mathrm{S}-\mathrm{T})$, especially if there is no reason for the property owner to install a green roof.

The SWOT balance for the private use of green roofs by the property owner shows a high motivation and the willingness to take financial risks, even with financial support of local authorities. The choice for an intensive green roof, if possible at all, seems to be more logic and beneficiary than for an extensive green roof.

\section{GREEN ROOFS FOR THE URBAN ENVIRONMENT}

To improve urban environmental quality, the greatest challenge with the largest profits will be obtained by using existing rooftops. Table 3 provides an overview of the factors related to the urban environment according the SWOT principles.

Table 3. SWOT analysis for green roofs on the urban scale (municipality)

\begin{tabular}{ccc}
\hline & \multicolumn{1}{c}{ Positive } & Negative \\
\hline Internal & $\begin{array}{c}\text { Strengths } \\
\text { Ability to reduce flood risks } \\
\text { Environmental benefits } \\
\text { Life quality and aesthetics }\end{array}$ & $\begin{array}{c}\text { Ownership } \\
\text { Performance }\end{array}$ \\
\hline External & $\underline{\text { Opportunities }}$ & $\underline{\text { Threats }}$ \\
& $\begin{array}{c}\text { Climate change } \\
\text { Public acceptance and awareness }\end{array}$ & $\begin{array}{c}\text { Non-committal green roof policy } \\
\text { Lack of knowledge }\end{array}$ \\
& Scepticism of potential adopters \\
\hline
\end{tabular}

\section{Strengths}

Ability to reduce flood risk, environmental benefits and life quality and aesthetics [11] are important benefits for the public space. Energy savings are less important for public space itself, but add indirectly to a better environmental quality [13] and the policy of reducing $\mathrm{CO}_{2}$.

Ability to reduce flood risk. Green roofs can be used as a measure for flood risk reduction because of their water storage and water run-off delay. Extensive green roofs may delay precipitation drainage by $50 \%$. In comparison, delayed drainage for gravel roofs is about 25\% [12]. Hydrological efficiency of green roofs depends on water storage of the soil, evaporation and the drainage system for run-off, but also the intensity and the frequency of showers is an important parameter. A study of STOWA [3] shows that $100 \%$ green roofs in an area has little effect on the run-off of heavy showers, whereas the same area of green roofs is effective for medium showers to prevent up to $50 \%$ storm water run-off. A Norwegian study [19] shows that the main factor that determines precipitation in relation to retention is evapotranspiration (influenced by several parameters such as temperature, solar radiation, type of vegetation and roof construction) and the antecedent dry weather period. A very humid and cold coastal climate often leaves too little time in between periods of precipitation for roofs to regenerate their storage capacity. 
An example of a calculation was made in 2005 by the municipality of Rotterdam: if $25 \%$ of the roofs of the Oud-Mathenesse area are replaced by green roofs with a capacity of $25 \mathrm{~mm}$, as can be required by most extensive roofs with a total package of $7 \mathrm{~cm}$, the annual overflow of the sewage system, causing water pollution, will be reduced by $19,5 \%$. In this calculation, the maximum reduction (based on an extreme shower which takes place once in 100 years) of overflow of the sewage system is $3.4 \%$ [3].

Environmental benefits. Reducing the effects of the UHI [1] is another important urban benefit for which green roofs act as a mitigation measure. Green roofs can decrease the temperature of a roof surface with $30-60{ }^{\circ} \mathrm{C}$ [25]. The cooling effect of green roofs is created by the evaporation of water from vegetation and substrate. Because evaporation needs heat, the ambient temperature drops. A larger surface of green or leaves (an intensive roof) means more cooling. In addition, the albedo of green roofs is higher than the albedo of black roofs, which means green roofs can reflect more sunlight.

Rainwater run-off quality is improved, not only because during hot summers rainwater remains cooler, which prevents all kinds of other negative effects of higher water temperatures, but also because the surface from which the water runs off determines its quality. Flat roofs are often more polluted than sloped roofs [8]. The quality of run-off water of green roofs on the other hand depends on soil material (e.g. compost) and added fertilizers [18]. Studies show that intensive green roofs even have 3 times less lead, 1.5 times less zinc, 3 times less copper and 2.5 times less cadmium contaminations in comparison to normal roofs [25]. In addition, cooler run-off rainwater lowers the temperature of surface water and thus prevents the spreading of bacterial diseases in hot periods (legionella for example).

Life quality and aesthetics. The greener the city, the more attractive the city may appear. Foreign examples (Basel or Stuttgart) show that green roofs are often combined with architectural highlights, as a landmark which attracts (international) attention [12]. Compensation for a lack of green on ground level is obvious if roofs are almost at ground level or otherwise publicly accessible, and cover a large area, such as parks on parking garages.

Acoustic reduction for ambient or traffic noise is also an interesting side-effect for the public space. Green roofs of low-rise buildings can in general reduce reverberation by approximately $3 \mathrm{~dB}[10,13,15]$.

Air quality and biodiversity might improve, though this has not been investigated thoroughly, and of course depends on the surface and type of green roof [13]. The contribution of sedum roofs to both air quality and biodiversity is not significant [26].

\section{Weaknesses}

Cost related weaknesses are as aforementioned merely a private and not a public concern. On urban scale these weaknesses result in two other weaknesses, ownership and performance of green roofs.

Ownership. Roof surface is needed for a city with a lack of space for green on ground level, but roof surface is no public property. The policy of municipalities has therefore been to stimulate roof owners to replace their black bituminous roofs by green roofs by subsidising green roof initiatives. A comparison of private costs versus public return for Rotterdam in 2008 [27] shows that for all districts the private return is negative (in average a shortage of $16 \mathrm{EUR} / \mathrm{m}^{2}$ ) while the public return is positive. A balance of both shows a positive balance for the city centre and densely built districts, while other districts show a negative balance. From 2008 green roofs were subsidized by the 
municipality with $25 \mathrm{EUR} / \mathrm{m}^{2}$ which is approximately a little less than half of the cheapest investment $\left(55 \mathrm{EUR} / \mathrm{m}^{2}\right)$ to be made by the building owner [27].

Performance. Another Dutch study [13] into the contribution of green roofs for urban ecosystems shows that extensive roofs are just a little better than traditional roofs, but that intensive roofs are almost the best of all investigated green elements, while in policy for green roofs these distinction is hardly made. Besides, the effect of individual green roofs, extensive or intensive, at ambient temperatures in urban areas is negligible, only a large surface of green roofs will have effect [25]. Results or numbers for this are yet unknown, as there are not many urban zones which have a high percentage of green roofs [13].

The performance of green roofs furthermore depends on various parameters such as type of green roof, choice of vegetation, irrigation and local climate. Its efficiency is also determined by the depth, density and humidity of the vegetation, as well as leaf area index, stomatal resistance, height, fractional coverage and albedo [16, 25]. Local climate varies not only between cities due to their geographic locations, but also within a city itself. For an optimal performance of green roofs a more specific and locally oriented research is needed [16], the application of just 'a green roof' does not guarantee that its performance meets local or regional needs.

\section{Opportunities}

External opportunities for green roofs on an urban scale are the development of cities to adapt climate change measures and a general public acceptance of green roof measures.

Climate change. Green roofs function as both mitigation and adaptation tools for climate change measures [5], and combine other environmental benefits as well. Because green roofs, even sedum roofs, are in any circumstances and location a better alternative than the commonly used black bituminous roof covering and add green areas without needing additional space, a policy to stimulate green roofs has been adopted by many cities, as aforementioned.

Internationally, some interesting measures for building legalization can be found. For example, in Chicago and Stuttgart a higher density of buildings is permitted if green roofs are applied [6]. Some other foreign cities (Linz, Tokyo, Toronto, Copenhagen, Vancouver, and Portland) have an obligation for green roofs in the application for building permits. To legalize green roofs for The Netherlands in the future, the quality of construction and maintenance can be prescribed in national NEN standards. These NEN standards are mandatory in Dutch building legislation [6].

Other measures as extended calculation programmes can include hidden social and environmental costs on the long term, such as the Dutch 'Maatschappelijke Kosten en Batenanalyse' (Social Costs and Benefits Analyses, www.mkba-informatie.nl) and The Economics of Ecosystems and Biodiversity (TEEB), www.teebweb.org.

Public acceptance and awareness. Green areas and green roofs stimulate psychological well-being and are therefore a measure easily accepted and mainly positively rewarded by the majority of citizen [11]. Social and psychological well-being can be influenced positively if (intensive) green roofs are used as meeting places, a greener city lowers criminal behaviour and creates more recreation opportunities for citizen [13].

\section{Threats}

A lack of knowledge and a sceptical attitude of potential adopters, as mentioned by Brudermann and Sangkakool [11] and as a result of weaknesses on the private scale, can 
be submitted as threats, or external negative forces on the urban scale. Incentives for private owners to achieve public benefits needs public responsibility which can only be arranged by local authorities. According to green roof policy, another threat can be distinguished on an urban scale, a too general or non-committal policy towards green roofs.

Non-committal green roof policy. Policies for green roofs have been studied for five different cities [7]. Basel and Stuttgart show strong environmental motives (biodiversity and clean air) and are securing their actions, while actions such as subsidies stimulated by Rotterdam and Chicago are mainly voluntary based. London only uses communication as an instrument. In line with the importance of their goals, the local authorities of Basel and Stuttgart, in contrast to Rotterdam, Chicago and London, are still involved in the evaluation stage, and take responsibility for monitoring and controlling green roof constructions. Furthermore, if green roofs are legally mandatory, the responsibility for applying green roofs is not a private decision anymore. This also has its effect on other stakeholders, such as the green roof suppliers and contractors. By lowering prices and making the application of green roofs more accessible for a larger group, eventually a positive upwards spiral will occur, as can be illustrated with the fact that in Basel and Stuttgart $25 \%$ of the eligible roofs are green, versus $1 \%$ in Rotterdam. An external threat could therefore occur if politics is not serious enough about its green roofs policy.

Another article [5] shows a gap between theoretical climate change measures and the practice of urban planning regarding heat stress and flood risks. Heat stress 'damage' has no direct costs for which local authorities are responsible. Damage by floods and functioning of the sewage system to the contrary, have direct links with responsibility of the municipality, both are, however, often not translated into specific actions or measures by urban planners. Green roofs can in this way be regarded as a 'no-regret' measure, positive for every environmental and climatological goal as well for the quality of the urban environment, and in this way remain a general solution resulting in a lack of responsibility as aforementioned, instead of a specific solution.

Illustrated for Rotterdam there is no overview of locations where green roofs are applied and which green roofs are applied (intensive or extensive). According to the municipality of Rotterdam, property owners in districts which need green roofs the most, such as the city centre, are the hardest to reach. A lot of buildings in the city centre (and their roofs) -shops or offices- are owned by people living abroad. In other densely built-up districts inhabitants are poor and many housing or apartment blocks are owned by housing companies. For both districts it is not effective to offer an incentive for voluntary green retrofitting of flat rooftops.

\section{Comparison}

Comparing opportunities to strengths $(\mathrm{O}-\mathrm{S})$, there is a high potential for using green roofs to improve quality of public urban space (environmental, flood risks, heat stress, air quality, biodiversity) which contribute to urban goals (green policy, climate adaption, public awareness).

The application and performance of green roofs though cannot be controlled by local authorities, as roof surface is mainly private property. Incentives for individual appliance do not guarantee enough square metres and the best green roof-types in public spaces where they should be needed $(\mathrm{O}-\mathrm{W})$.

External threats such as a non-committal policy, lack of information and importance and a sceptical attitude of potential adopters, can lead to using green roofs as a no-regret measure (S-T), which reinforces inefficient distribution of subsidies leading to a less contributing performance of green roofs on an urban scale (W-T). 
In general, though green roofs show a lot of potential for the urban environment, a non-committal policy is impeding rather than promoting green roofs as an instrument to make a city more resilient.

\section{DISCUSSIONS}

Policies do not distinguish between extensive and intensive green roofs. Both types of roofs have similar benefits for the urban environment with a different impact. For all challenges, intensive green roofs will be a better solution than extensive green roofs, but intensive roofs often need constructive adjustments and are therefore not easy and cheap to use for retrofitting, if possible at all.

Furthermore, not all urban districts have the same environmental challenges. A dense city centre probably needs a larger area of green surface for cooling and water storage, but a suburb could have enough gardens or parks to prevent climate change effects. It is better to study which local measure is the best for its specific local challenge. If policy tolerates different financial constructions for different districts, municipalities could divide cities into districts and decide per district the main problem and the preferred planning solution. Also, the presence of flat roofs, the type of sewage system (combined or separate) and the possibility for cheaper alternatives in the district, as well as the construction of ownership in its social context should be worth investigating more closely. For heat and flooding risk challenges, a 'recommendation' map could be made, which localizes diverse measures for urban climate adaption [2].

In this paper the function of green roofs is reviewed under conditions of The Netherlands. Rainwater retention is the most import challenge for this climate, but as green roofs are beneficial for several climate-change effects at the same time, other climates can use green roofs for another goal. The UHI effect for example will cause a serious environmental hazard in Mediterranean cities. Plant drought in these climates is something to pay attention to for the choice of vegetation and irrigation opportunities. For application in a very humid coastal climate on the other hand, where plant drought is of no concern, attention must be given to water storage capacity regeneration, or choice of the green roof type, in between periods of precipitation. Again a local or regional approach towards benefits and costs of green roofs is necessary.

New developments are worth following as they could contribute to special challenges, for instance the so called Dutch 'polder roof' (www.polderroofs.nl), a green roof especially made for water storage. Green roofs which can generate electricity are interesting as well [16].

The author is aware of the fact that this paper uses the results of other papers. This paper also remains on an overall level to show on an abstract level, with help of SWOT frameworks, how mechanisms between different ownerships are regulated and influenced.

\section{CONCLUSIONS}

A general SWOT analysis made by Brudermann and Sangkakool, in which public and private factors are combined, shows different results if it is split into two different SWOT frameworks for each spatial scale. Salient in combining the two SWOT frameworks is that weakness and threats can be addressed to private owners, while strengths and opportunities are mainly public benefits, which has also been concluded by the authors themselves. Furthermore, their conclusion remains general and quite optimistic, with four strategies to overcome threats and weaknesses: green roof policies, financial compensation, educational and promotional activities and a clear communication about the positive contribution of green roofs. The division of most factors between private and public scale, however, shows that these measures are not sufficient, and that policies 
must take a leading and dominant role, as public internal weaknesses are weakening the private weaknesses and public and private opportunities are dominated by policy, while external threats and internal weaknesses influence each other negatively on, and within, both scales.

For extensive roofs, there are fewer benefits but more opportunities for the municipality, for property owners, however, intensive roofs are if possible a much better choice (O-S). The most important benefits or strengths for the urban environment (water storage, reduction of heat stress) are less important for the building owner, benefits for the property owner on the other hand are mainly based on an improvement of quality, such as additional living space, a better view or a more comfortable inner climate, as this reassures return of investment the most. There are almost no other important reasons for applying green roofs individually. Because intensive green roofs are accessible and also offer the urban environment significant benefits, the consideration for property owners should be mainly focussed on the appliance of multifunctional intensive green roofs.

However, for retrofitting the existing building stock with green roofs, these considerations are irrelevant, as most old buildings do not have the bearing capacity for intensive roofs. Furthermore, comparing weaknesses to opportunities on both scales $(\mathrm{O}-\mathrm{W})$, the internal weakness of a random and scattered share of mostly green extensive roofs for municipality roofs does not add significantly to an improved and resilient urban space. Densely built districts where green roofs are needed, most are the hardest to reach because of more urgent social challenges in those, generally poorer, districts. With a non-committal policy of green roofs, the need of applying a green roof is absent for most property owners. Especially if return of investment costs is unclear, and if there is a lack of information regarding construction risks or damage.

For the urban scale, the greatest benefit of green roofs, a combination of several environmental and climatological benefits at the same time, cannot be replaced by alternative or cheaper techniques. The worst scenario for urban water and heat challenges is an area of black bituminous roof surface. This can be seen as the reason why so many municipalities use a green roof policy as a no-regret measure. Unfortunately, combined with threats (W-T) a non-committal and market-oriented policy with no responsibilities for constructing or controlling in the first stage of implementing and no mandatory regulations, leads to voluntary participation which does not, as shown before, have the impact that green roofs could have on the urban space. To use green roofs for the public benefit, the responsibilities for green roofs has to be for local authorities as well. Next to all, environmental and economic considerations other factors are important, such as aesthetics and personal, social or psychological perceptions.

Extensive green roofs can be better regarded as building material or green urban infrastructure with benefits for the urban environment. Therefore also the responsibility for the choice whether or not to apply green roofs for the public benefit must remain public.

In case alternative measures on ground level, or on other levels which are public property already, can reduce climatological impacts sufficiently and cheaper, it must be accepted that green roofs in general will stay a no-regret measure with some, merely visible and possible psychological, contribution.

If green roofs are seriously needed for future challenges, green roof-types must be studied regarding their local contribution (climatological conditions, vegetation possibilities and so on), instead of their general benefits, in order to focus attention to the most efficient option in the wide range of green roofs types. In the first stage of implementing, green roofs are to be made a mandatory requirement (for new buildings and/or retrofitting). Local authorities should stay responsible for a successful green roof policy. To continue this policy efficiently, further research on local climatological demands in relation to its social context is needed to use specific, realistic and effective 
targets and guidelines in urban planning. Furthermore, information, communication and also evaluation of applied green roofs must be set up as well as possible in order to counter the threats of a lack of knowledge and scepticism to eventually boost green roof market, builders, architects and industry, and continue in an upwards spiral.

\section{REFERENCES}

1. Kleerekoper, L., Van Esch, M. and Salcedo, T. B., How to make a City Climate-proof, addressing the Urban Heat Island Effect, Resour. Conserv. Recycling., Vol. 64, pp 30-38, 2012, https://doi.org/10.1016/j.resconrec.2011.06.004

2. Lenzholzer, S., Weather in the City-How Design Shapes the Urban Climate, Nai 010 Uitgevers/Publishers, Rotterdam, The Netherlands, 2015.

3. Broks, K. and Luijtelaar, H., A closer look at green Roofs: The Effects of green Roofs in broad Perspective with Focus on Urban Water management (in Dutch), Stichting Toegepast Onderzoek Waterbeheer, Amersfoort, The Netherlands, 2015.

4. Wong, N. H., Tay, S. F., Wong, R., Ong, C. L. and Sia, A., Life Cycle Cost analysis of Rooftop Gardens in Singapore, Build Environ., Vol. 38, No. 3, pp 499-509, 2003 , https://doi.org/10.1016/S0360-1323(02)00131-2

5. Runhaar, H., Mees, H., Wardekker, A., van der Sluijs, J. and Driessen, P. P., Adaptation to Climate change-related Risks in Dutch Urban Areas: Stimuli and Barriers, Regional Environmental Change, Vol. 12, No. 4, pp 777-790, 2012, https://doi.org/10.1007/s10113-012-0292-7

6. Hop, M. and Hiemstra, J., The Strategy of Roof and Facade green (in Dutch), 2014.

7. Mees, H. L., Driessen, P. P., Runhaar, H. A. and Stamatelos, J., Who governs Climate adaptation? Getting green Roofs for Stormwater retention off the Ground, J. Environ. Plann. Manag., Vol. 56, No. 6, pp 802-825, 2013, https://doi.org/10.1080/09640568.2012.706600

8. Pötz, H., Bleuzé, P., Sjauw, En Wa A. and Baar, T. V., Urban green-blue Grids for sustainable and dynamic Cities (in Dutch), Coop for Life, 2012.

9. Oberndorfer, E., Lundholm, J., Bass, B., Coffman, R. R., Doshi, H., Dunnett, N., Gaffin, S., Köhler, M., Liu, K. K. Y. and Rowe, B., Green Roofs as Urban Ecosystems: Ecological Structures, Functions, and Services, Bioscience, Vol. 57, No. 10, pp 823-833, 2007, https://doi.org/10.1641/B571005

10. Vijayaraghavan, K., Green Roofs: A critical review on the Role of Components, benefits, limitations and Trends, Renewable and Sustainable Energy Reviews, Vol. 57, pp 740-752, 2016, https://doi.org/10.1016/j.rser.2015.12.119

11. Brudermann, T. and Sangkakool, T., Green Roofs in Temperate Climate Cities in Europe - An analysis of Key decision Factors, Urban Forestry \& Urban Greening, Vol. 21, pp 224-234, 2017, https://doi.org/10.1016/j.ufug.2016.12.008

12. Hendriks, C., Snep, R., de Vries, E. and Brolsma, R., Green Roofs in Tilburg (in Dutch), Report, Alterra Research Institute, Wageningen, The Netherlands, 2016.

13. Hop, M., Hiemstra, J. A., Ecosystem Services of green Roofs and Façades: A Literature Study on Services at the Level of Neighborhood and City (in Dutch), 2013.

14. Teeuw, P. G. and Ravesloot, C. M., Grown Roofs after 2010: Alignment of Technology, Organization \& Social Interest (in Dutch), Techne Press, Amsterdam, The Netherlands, 2011.

15. Berardi, U., GhaffarianHoseini, A. and GhaffarianHoseini, A., State-of-the-art analysis of the Environmental benefits of green Roofs, Appl. Energy., Vol. 115, pp 411-428, 2014, https://doi.org/10.1016/j.apenergy.2013.10.047

16. Carmona García, C. E. and Carvajal Muñoz, J. S., Global research Trends in green Roofs: Benefits, main developments and future needs, Produccion Limpia, Vol. 10, No. 2, 2015. 
17. Fioretti, R., Palla, A., Lanza, L. G. and Principi, P., Green Roof Energy and Water related Performance in the Mediterranean Climate, Build. Environ., Vol. 45, No. 8, pp 1890-1904, 2010, https://doi.org/10.1016/j.buildenv.2010.03.001

18. Berndtsson, J. C., Green Roof Performance towards management of runoff Water Quantity and Quality: A review, Ecol. Eng., Vol. 36, No. 4, pp 351-360, 2010, https://doi.org/10.1016/j.ecoleng.2009.12.014

19. Johannessen, B. G. and Muthanna, T., Hydraulic Performance of extensive green Roofs in cold Climate, Conference Paper, Novatech, Lyon, France, 2016.

20. Lehmann, S., Low Carbon Districts: Mitigating the Urban Heat Island with Green Roof Infrastructure, City, Culture and Society, Vol. 5, No. 1, pp 1-8, 2014, https://doi.org/10.1016/j.ccs.2014.02.002

21. Susca, T., Gaffin, S. R. and Dell'Osso, G., Positive Effects of Vegetation: Urban Heat Island and green Roofs, Environmental Pollution, Vol. 159, No. 8-9, pp 2119-2126, 2011, https://doi.org/10.1016/j.envpol.2011.03.007

22. Zinzi, M. and Agnoli, S., Cool and green Roofs, An Energy and Comfort comparison between passive cooling and mitigation Urban Heat Island Techniques for residential Buildings in the Mediterranean Region, Energy Build., Vol. 55, pp 66-76, 2012, https://doi.org/10.1016/j.enbuild.2011.09.024

23. Gagliano, A., Detommaso, M., Nocera, F. and Berardi, U., The adoption of green Roofs for the retrofitting of existing Buildings in the Mediterranean Climate, International Journal of Sustainable Building Technology and Urban Development, Vol. 7, No. 2, pp 116-129, 2016, https://doi.org/10.1080/2093761X.2016.1172279

24. Olivieri, F., Di Perna, C., D’Orazio, M., Olivieri, L. and Neila, J., Experimental measurements and numerical Model for the Summer performance assessment of extensive green Roofs in a Mediterranean Coastal Climate, Energy Build., Vol. 63, pp 1-14, 2013, https://doi.org/10.1016/j.enbuild.2013.03.054

25. Saadatian, O., Sopian, K., Salleh, E., Lim, C., Riffat, S., Saadatian, E., Toudeshki, A. and Sulaiman, M. Y., A review of Energy Aspects of green Roofs, Renewable and Sustainable Energy Reviews, Vol. 23, pp 155-168, 2013, https://doi.org/10.1016/j.rser.2013.02.022

26. Rowe, D. B., Green Roofs as a means of pollution abatement, Environmental Pollution, Vol. 159, No. 8-9, pp 2100-2110, 2011, https://doi.org/10.1016/j.envpol.2010.10.029

27. Klooster, J., Moppes, D. V., Bes, E. and Goedbloed, D., The Financial return on green Roofs in Rotterdam (in Dutch), $\mathrm{H}_{2} \mathrm{O}$, Vol. 24, pp 23-25, 2008.

28. Dyson, R. G., Strategic development and SWOT analysis at the University of Warwick, Eur. J. Oper. Res., Vol. 152, No. 3, pp 631-640, 2004, https://doi.org/10.1016/S0377-2217(03)00062-6

29. Doug B, Hitesh D, James L, Paul M., Report on the Environmental benefits and costs of green Roof Technology for the City of Toronto, Report, Ryerson University, Toronto, Ontario, Canada, 2005. 